\title{
Publishing Through Some Sites on the Internet
}

\author{
Hedaya Alasooly \\ Ministry of Telecommunication and Information Technology, \\ Gaza, Palestine,
}

hasooly@gov.ps

\begin{abstract}
The paper provides a survey of some of the international journal publishers that can be found in internet. Provided also is a survey of some of the free and commercial publishers in internet.
\end{abstract}

Keywords: Publishing, Journal, International Publishers.

\section{Introduction}

The paper provides a survey of some of the international journal publishers that can be found in the Internet. It also provides a survey of some of the free and commercial publishers in the Internet.

In fact, publishing was of special interest for me, because I wanted to find some way to publish my articles.

The work is composed of the following parts,

Section 1: Lists some of the free publishing providers for your articles.

Section 2: Lists some of the international journal publishers.

Section 3: Lists some of the commercial publishing providers for your books.

\section{List of Free Publishing Providers}

There is bulk number of publishing providers in the net, and a lot of them are listed on publishing.info $<\underline{\text { http://www.opublishing.info }}>$. It is not easy to find free ones. Only Lulu self publishing company allows you to sell your books with them for free. There are a lot of web sites that that allow you to post your article or abstract in a form of blog. The best ones to promote the articles to search engines are www.lulu.com, www.searchwarp.com, www.shvoong.com, www.writing.com and www.helliumeknowledge.com. I just noted that www.searchwarp.com and www.helliumeknowledge.com will review the article before accepting to post it.

Material published as part of this publication, either on-line or in print, is copyrighted by the Informing Science Institute. Permission to make digital or paper copy of part or all of these works for personal or classroom use is granted without fee provided that the copies are not made or distributed for profit or commercial advantage AND that copies 1) bear this notice in full and 2) give the full citation on the first page. It is permissible to abstract these works so long as credit is given. To copy in all other cases or to republish or to post on a server or to redistribute to lists requires specific permission and payment of a fee. Contact Publisher@InformingScience.org to request redistribution permission.

\section{www.Iulu.com}

Lulu.com is the cheapest place for publishing a book and promoting it to search engines, as they don't take any fees for publishing, but they take a commission and pay you a royalty for each book sold. The major disadvantages are, they don't review or edit your book, and they don't market the book, 
so mostly you will not have sales with them. I published most of my works with them. You can go through one of my books: http://www.lulu.com/content/332066

\section{WWW.shvoong.com}

They provide the opportunity to post an abstract and earn some money if your abstract gained the attention of the readers. I used it to post the abstracts of most of my works. You can go through one of them: http://www.shvoong.com/books/253321-free-voice-ip-calls/

\section{www.searchwarp.com}

It is possible to post an article under their website for free. My special note is that, they review the article before accepting to post it, and you can submit the article to many search engines. You can go through one of my articles with them: http://searchwarp.com/swa71045.htm

\section{www.writing.com}

Here also, possible to post an article under their website for frees. They have good writing environment. They don't review the article, but they submit it to the search engines. My article with them: http://www.writing.com/main/view item/item_id/1120891

\section{www.heliumknowledge.com}

It is possible to post an article under their website for free. My special note is that, they review your article before accepting to post it, and you can find the article in the search engines. You can go through one of my articles with them: http://www.helium.com/tm/66890/overviewthis-reportafter-weeks

\section{WWW.articlesgratuits.com}

Here also, possible to post an article under their website for frees. You can go through one of my articles with them: http://www.en.articlesgratuits.com/free-voice-over-ip-voip-calls-id686.php

\section{www.newyorkliteraryagency.com}

I applied to post my manuscript with them, and they asked to email my manuscript to be reviewed within 2-4 weeks.

\section{www.blogomonster.com}

It is possible to post an article under their website for free. You can go through one of my articles with them was (removed after) http://www.blogomonster.com/hedaya/79367/

\section{www.gigablogs.net}

Here also, possible to post an article under their website for frees. You can go through one of my articles with them http://www.gigablogs.net/blog/dr_hedaya_al asooly_article/general/2006/06/19/free voice_over ip_calls

\section{www.21publish.com}

Here also, possible to post an article under their website for frees. You can go through one of my articles with them: http://hedaya.21publish.com 


\section{www.blogs.ittoolbox.com}

After submission, they give you a message that your information has been submitted for review to ensure the blog meets the basic community standards.

\section{www.weishare.com}

It is possible to post an article under their website for free. Their web site is https://www.weishare.com

\section{International Journal Publishers}

Actually it is not easy to get a journal that can accept your work if it does not meet the following requirements:

- The scope of topics that the journal publishes.

- The paper should be written in some standard style that is acceptable for the journal.

- Same paper should not be published or submitted to other journals.

- Most of the journals accept only research type of works, with high degree of originality, and don't accept a quick technical works.

Most journals allow you to submit your paper through a manuscript center or editorial manager after registration, so you can check the status and the progress of your submission while your work is processed with them, and some ask you to submit the paper through email, or through quite simple web interface.

Some sites have a directory of most known journal publishers and conferences, for example, www.isworld.org, ejournals.ebsco.com, www.doaj.org, www.eco-web.com/register, www.atypon-link.com and www.computer.org/conferences.

I will present here only some of the international journals and conferences that I tried to deal with, as there are a bulk number of publishers, and I can't survey all of them.

\section{Institute of Electrical and Electronics, Inc. (IEEE)}

They publish bulk number of transactions, proceedings and magazines in most areas, and it was easy to submit and check the status of your paper through manuscript center, and if the paper was rejected, they have quite good reasons for that. Their official web site is www.ieee.org. Some of their journals in the computer and communication fields are:

- IEEE Computer Graphics \& Applications (http://cs-ieee.manuscriptcentral.com).

- IEEE IT Professional (http://cs-ieee.manuscriptcentral.com).

- IEEE Software (http://cs-ieee.manuscriptcentral.com).

- ACM Transactions on Networking (http://mc.manuscriptcentral.com/tnet-ieee).

- IEEE Transactions on Communications (http://mc.manuscriptcentral.com/tcom).

- IEEE Communications Surveys and Tutorials (http://comst-ieee.manuscriptcentral.com).

- IEEE Transactions on Mobile Computing

- Transactions on Wireless Communications ( http://mc.manuscriptcentral.com/twc).

- IEEE Communications Magazines (http://commag-ieee.manuscriptcentral.com). 
- IEEE Network: Email: bisdik@us.ibm.com.

- IEEE Internet Computing.

\section{Institution of Engineering and Technology (IET)}

They publish some of the proceedings and magazines, but I did not see that they pay attention for the paper. Some of their proceedings:

- IEE proceedings of computer and digital network (http://mc.manuscriptcentral.com/iee/cdt).

- IEE proceedings of communication (http://mc.manuscriptcentral.com/iee/com ).

\section{Elsevier Science}

From their web site, www.elsevier.com, you can choose the suitable journal and submit your manuscript. The submission is done through editorial manager. Some of their journals in the computer and communication fields are:

- Journal of Information \& Software Technology (http://www.editorialmanager.com/infsof).

- Electronic Commerce Research and Applications (http://ees.elsevier.com/ecra/default.asp).

- Computer Communications (http://ees.elsevier.com/comcom).

- International Journal of Computer-Supported Collaborative Learning. (http://ijcscl.edmgr.com).

- Computer Networks (http://comnet.editorialmanager.com).

\section{Association for Computing Machinery (ACM)}

They publish bulk number of journals and transactions. Some of their journals in the computer and communication areas are:

- IEEE/ACM Transactions on Networking (http://mc.manuscriptcentral.com/tnet-ieee)

- Transactions on Information Systems (TOIS) (http://mc.manuscriptcentral.com/acm)

- Transaction on Internet Technology (http://mc.manuscriptcentral.com/acm/toit)

- Transactions on the Web (http://mc.manuscriptcentral.com/acm/tweb)

- Computing Survey (http://mc.manuscriptcentral.com/acm/csur)

- Transactions on Multimedia Computing, Communications, and Applications manuscript (http://mc.manuscriptcentral.com/acm/tomccap).

- Internet Computing.

\section{Idea Group Publishing}

Some of their journals in the computer area,

- International Journal of Cases on Electronic Commerce: Email: ijcec@idea-group.com.

- International Journal of Information and Communication Technology Education: Email: tomei@rmu.edu. 
- International Journal of Information Technology and Web Engineering: Email: alkhatib.ijitwe@qu.edu.qa, DavidCRine@,aol.com.

- Journal of Cases on Information Technology (JCIT): Email: jcit@idea-group.com

- International Journal of Web Services Research: Submission is through online submission system.

- International Journal of Web-Based Learning and Teaching Technologies: Email: esnault@em-lyon.com.

\section{Wiley Publisher}

Their official web site is http://www3.interscience.wiley.com. Some of their journals in the computer area:

- The International Journal of Communication Systems (http://mc.manuscriptcentral.com/ijcs).

- Information Technology for Development (http://mc.manuscriptcentral.com/itd)

- International Journal of network management (http://mc.manuscriptcentral.com/nem)

\section{Blackwell Publishing}

One of their journals in the computer area:

- The Journal of Computer-Mediated Communication (http://mc.manuscriptcentral.com/jcmc).

\section{Emerald Group Publishing Ltd}

Their web site is

http://jade.emeraldinsight.com/servlet/ContentServer?pagename=Emerald/AuthorHome. They publish many journals. Generally you will submit through Emerald Group online submission system.

\section{INFOCOMP Journal of Computer Science (INFOCOMP)}

Their web site is https://submissoes.sbc.org.br. In this site you can find after registration a list of conferences, in which you can submit your paper under.

\section{EDAS}

Their web site is http://edas.info/index.php. In this site you can find after registration a list of conferences, in which you can submit your paper under.

\section{COCUS Conference Management System}

Their web site is http://cocus.create-net.it/cocus/login/loadHome.do. In this site you can find after registration a list of conferences, in which you can submit your paper under.

\section{Information Institute}

In their web site, www.conferencemanagementsystem.net, you can find a list of conferences, in which you can submit your paper under. 


\section{IEEE Computer Society}

In their web site, www.computer.org conferences, you can find a list of conferences, in which you can submit your paper under.

\section{Penton Media}

They publish some journals. You need to send your paper to karen@windowsitpro.com.

\section{Specialized Systems Consultants, Inc.}

They publish some journals. One of their journals is Linux journal. The submission guide is in http://www.linuxjournal.com/xstatic/author/authguide, Email: 1jeditor@ssc.com.

\section{Enformatica.org}

They organize a lot of conferences, and the submission is through email info@enformatika.org. The acceptance rate is high.

\section{Informing Science Institute}

In their web site, http://informingscience.org, you can find after registration a list of conferences and journals, in which you can submit your paper under.

\section{List Of Commerical Book Publishing Providers}

There is bulk number of commercial publishing providers for books in the net, and a lot of them are listed opublishing.info.

As a self publisher, there are three questions you should ask yourself before you begin to write.

1 . Who is my book for?

2. How will I get it printed?

3. How will I publicize and sell it?

There is a good guide at www.merlin-publishing.com that teaches how to publish your own book: Who is Your Book for?, Getting Your Book Printed, Principles of Writing, Design and Layout, Publicity and Pricing, Media Promotion, Getting your Book Listed and Using Your Own Imprint.

In this section, I will only list some of the commercial book publishing providers that I went through, and my general note about them.

\section{Authorhouse}

I just tried to make registration, but they ask for book id. I sent them an email to authorsupport@authorhouse.com to ask about book id, but no answer.

\section{iUnivers}

I just registered but I could not publish with them, as I have to subscribe to one of their non free packages.

\section{www.mondialbooks.com}

They asked me to wait 3 weeks to review my abstract and send me back 


\section{www.whitmorepublishing.com}

I registered and they asked me to get a guideline. I received an email which asks me to send my submission and wait answer for 6 weeks.

\section{Outskirts Press}

I have to register, and choose the publishing package, and then they will review my manuscript and approve it to continue.

\section{Tate Publishing}

They asked me to register, and upload my file, then wait an email. When I asked them about if their service is free, they answered that it cost a lot.

\section{Book Surge:}

I sent question to them. I received an email to answer some questions. After that, they gave me an offer for $\$ 600$ package for their publishing service.

\section{Raider}

I sent question to them, they replied that their publishing fee is $600 \$$.

\section{Digital Delta}

You have to send the manuscript through mail and wait their answer. Email:

prepress@digitaldata-corp.com .

\section{Morris Publishing}

Upon receipt of your material, they'll prepare your book and send you a free proof, allowing you to review your book before it's printed. After you have approved the proof, your books will be printed, bound, and shipped to you.

\section{www.blogit.com}

You need to choose in between many subscription plans to be able to publish with them.

\section{Dog Ear}

You can pick a package, and call them to sign up, then submit your materials

\section{Xlibris}

I registered and they asked me to wait their kit to know how to publish. Their packages cost from $500 \$-2000 \$$.

\section{Book Master}

I sent them email to know how they provide their service, they answered that they print only, not publishing.

\section{8hrs Book}

Your fill out their spec sheet, send them your files, then you approve the pdf soft proof that they send, and they'll print, bind and ship within 2 business days. 


\section{Wheatmark}

You need to download the publishing order form, prepare the manuscript and submit your materials (Payment, the publishing order form and the manuscript). Their package price around $800 \$$.

\section{www.knowldge-download.com}

They have good guide for writing, publishing and building a website for your e-book with them. You have to order to publish with them.

\section{Copy Guy.Com}

They ask to send the file by email. They told me that they are not publishing company, but they are print and ship the paid orders.

\section{Ebook-Time}

They are publishing company, with packages around 400-700\$

\section{BooksjustBooks}

I don't see registration options. But, there is good frequently asked questions guide.

\section{Online-Book-Publishing-Review - Toptenrevirws.Com}

This site compares some of what he considers the best publishers. iUniverse, AuthorHouse, Infinity Publishing, Virtualbookworm Publishing, Llumina Press, Outskirts Press, Xlibris, eBookstand, Fultus, Aventine Press, BookLocker. A table showing their comparison is available at http://online-book-publishing-review.toptenreviews.com/online-publishing-your-book-yourrights.html

\section{Conclusion}

The paper gave a survey of some of the international journal publishers that can be found in internet. It also provided a survey of some of the free and commercial book publishing providers in internet. Lulu.com is the cheapest place for publishing a book and promoting it to search engines, as they don't take any fees for publishing, but the opportunity to sell the book is not high. I can say that Institute of Electrical and Electronics, Inc. (IEEE) is the best for journal publishing, as they review the paper well and they give good reasons for rejecting the paper, but the opportunity for accepting the paper is not high. If an author got a difficulty in finding a journal that can publish his work, he can seek a conference, but the registration to conferences costs a lot.

\section{References}

[1] http://www.opublishing.info

[2] http://www.lulu.com web site.

[3] http:// www.iswrld.org web site.

[4] http://ejournals.ebsco.com web site.

[5] www.merlin-publishing.com web site 


\section{Biography}

Dr. Hedaya Mahmood Alasooly has a Ph.D in Electrical Engineering from Czech Technical University and a M.Sc. in Electrical Engineering from Bahrain University. Dr. Alasooly is working now in Palestine Ministry of Telecommunication and Information Technology in Computer Networking Department.

PhD Thesis: Modeling and Control of Facts Devices and Active Filters for Load Flow Control and Power System Harmonics Elimination and Power System Stability Enhancement.

M.Sc. Thesis: Optimal and Suboptimal Control of SMES Devices for Power System Stability Enhancement.

The author has many publications in computer, most of them in www.lulu.com book store, search keyword "hedaya alasooly" and preview the works. Email Address: hasooly@gov.ps, hedaya_alasooly@yahoo.com.,www.geocities.com/hedaya_alasooly 